\title{
Toxicological and ecotoxicological aspects of tartrazine yellow food dye:
} a literature review

Aspectos toxicológicos e ecotoxicológicos do azocorante alimentar amarelo tartrazina: uma revisão de literatura Janete da Silva ${ }^{1}$, Renata Fracacio ${ }^{1}(\mathbb{D})$

\begin{abstract}
A B S T RAC T
The use of the tartrazine yellow additive in food products for human consumption is permitted within the acceptable daily intake of $7.5 \mathrm{mg} /$ $\mathrm{kg}$ of body weight per day (following the Joint Expert Committee on Food Additives standards). However, studies have described this as a toxic component. The dye, which is intensively used in the industry and commerce, enters the aquatic environment through releases of non-treated or inadequately treated effluents; however, further ecotoxicological research is needed. We addressed studies reporting the toxic effects of the exposure to this dye developed in humans, guinea pigs, and Danio rerio (a fish with molecular bases and genomes similar to humans). Based on this review, the doses allowed for acceptable daily intake, or even lower, toxic effects, can be evidenced for different organisms, life stages, and tested times. The reported values may not be protective to aquatic life. In a paper about the exposure of $D$. rerio from embryos to larvae kept at values lower than 0.05 and 0.5 g. $\mathrm{L}^{-1}$ for pure and commercial tartrazine, there was ecotoxicological effect for embryos and larvae 48 hours after hatching, which implied cardiac edema, changes in the yolk sac, scoliosis, and tail distortions.
\end{abstract}

Keywords: CENO; food additive; environmental legislation; Danio rerio; mutagenicity.

\begin{abstract}
RE S U M 0
O uso do aditivo amarelo tartrazina é legalizado para aplicação em produtos alimentícios para consumo humano dentro do valor de ingestão diária aceitável (IDA) de 7,5 mg/ $\mathrm{kg}$ de peso corpóreo por dia (seguindo os padrões da Joint Expert Commitee on Food Additives). No entanto, estudos descrevem este aditivo como tóxico. O corante, usado intensamente na indústria e no comércio, adentra o ambiente aquático por meio de lançamentos de efluentes sem tratamentos ou tratados inadequadamente; no entanto, novas pesquisas ecotoxicológicas são necessárias. Portanto, esta pesquisa elencou estudos cujos efeitos tóxicos da exposição ao referido corante se desenvolveram em seres humanos, cobaias e Danio rerio (peixe com bases moleculares e genoma similares aos humanos). Concluímos, de acordo com a literatura, que mesmo em doses permitidas para a IDA, ou até menores, há evidências de efeitos tóxicos para diferentes organismos, fases de vida e tempos testados. Os valores relatados podem não ser protetivos à vida aquática. Em um trabalho de exposição de $D$. rerio, desde embriões até larvas, mantidos em concentrações de 0,05 e 0,5 g. $\mathrm{L}^{-1}$ para tartrazina pura e comercial, observou-se que, na menor concentração, houve efeito ecotoxicológico em embriões e em larvas após 48 horas da eclosão, que implicou em edema cardíaco, alterações no saco vitelínico, escoliose e distorções na cauda.
\end{abstract}

Palavras-chave: CENO; aditivo alimentar; legislação ambiental; Danio rerio; mutagenicidade.

\footnotetext{
${ }^{1}$ Universidade Estadual Paulista "Júlio de Mesquita Filho" - Sorocaba (SP), Brazil.

Correspondence address: Renata Fracacio - Avenida Três de Março, 511 - Bairro Aparecidinha - CEP: 18087-180 - Sorocaba (SP), Brazil E-mail: renata.fracacio@unesp.br
}

Conflicts of interest: the authors declare that there are no conflicts of interest.

Funding: Fundação de Amparo à Pesquisa do Estado de São Paulo, process no. 2018/05650-7.

Received on: 04/14/2020. Accepted on: 09/01/2020

https://doi.org/10.5327/Z21769478746 


\section{Introduction}

Colors fascinate human perception. In food, they are related to health and taste. Although these additives do not add nutritional value to the food, their use is intended, among other purposes, to intensify the natural color and extend their shelf life (FREITAS, 2012; ANASTÁCIO et al., 2016). The most used dyes include those from the azo group $(-\mathrm{N}=\mathrm{N}-)$, due to their high solubility, low cost, and better fixation on food. This group represents more than $65 \%$ of the commercial dyes (ZANONI; YAMANA, 2017). In Brazil, 11 artificial organic dyes are allowed, of which six are azos: tartrazine yellow, twilight yellow, amaranth, azorubin, ponceau $4 \mathrm{R}$, and red 40 .

The application of these additives to food must not exceed the maximum quantity allowed by the legislation: 0.5 g.1000 mL) (Resolutions 382, 383, 385, 388 e 389 - BRASIL, 1999a; 1999b; 1999c; 1999d; 1999e). However, quantitative analyzes of dye intake by the population require the identification of food products with additives in the consumer's diet, the estimation of additive concentration in these products, and the daily consumption knowledge, which should not exceed the acceptable daily intake (following the Joint Expert Committee on Food Additives - JECFA). For the tartrazine yellow dye, which is one of the most used in the food industry, the acceptable daily intake is $7.5 \mathrm{mg}$.kg of body weight per day, which would not cause health risks.

Morais (2010) studied individuals prone to allergic rhinitis, bronchial asthma, urticaria, or sensitivity to non-steroidal anti-inflammatory drugs, providing them acceptable daily intake doses of tartrazine yellow dye for seven days. The investigator observed that these individuals had a significant reduction in the peak of expiratory flow and presented angioedema, nasal congestion, rhinorrhea, wheezing, itchy skin, and urticaria, corroborating the data obtained by Doguc et al. (2013), Khayyat et al. (2017), and Bhatt et al. (2018).

Corder and Buckley (1995) proved in clinical respiratory studies that patients sensitive to tartrazine developed bronchoconstriction with consequent decrease in the respiratory volume. There is a group of people whose sensitivity to this dye is manifested as asthma, urticaria, and hypersensitivity to tartrazine, which occurs in approximately $3 \%$ of the population, mainly in individuals sensitive to salicylates. As the chemical structure is close to that of benzoates, salicylates, and indomethacin, allergic cross-reactions may occur. (POLÔNIO; PERES, 2009). Matsuo et al. (2013) analyzed the effect of tartrazine on histamine release (a hormone responsible for several allergic symptoms) in basophils (important cells of the immune system) of individuals that had chronic allergy-related conditions, such as urticaria.

Tartrazine has also been associated with behavioral changes, such as attention deficit and hyperactivity. Baterman et al. (2004) applied dye mixtures in the presence of sodium benzoate, in a double-blind experimental study using placebo in children at preschool age, and demonstrated that artificial dyes have a relevant influence on the hyperactive behavior of children aged about three years old.

Al-Shabib et al. (2017) showed that tartrazine can cause amorphous aggregation of proteins in the cationic form, which is known to cause various diseases and metabolic irregularities. Sasaki et al. (2002) proved the occurrence of DNA damages in mice colon in a comet assay at doses of 10 mg.kg.pc.day (mg per kilogram of body weight per day). They concluded that the azo dye, when ingested, is absorbed by the intestinal epithelium and metabolized by azo reductases elaborated by microorganisms from the intestinal flora and by hepatic reductases, which convert it into aromatic amines.

As toxicological effects were detected in humans and guinea pigs, it is likely that its release in water bodies can interfere with aquatic biota. Some papers were performed with the $D$. rerio organism, a model organism widely used in various biological, biomedical, toxicological, and ecotoxicological research, due to its $70 \%$ genetic homology with humans and to the advantages provided by its transparent embryos that permit detailed analyses of its development. These studies showed that the dye is harmful to embryos and larvae, for which development was negatively affected (JOSHI; KATTI, 2017; GUPTA et al., 2019; JIANG et al., 2020; SILVA; FRACÁCIO, 2020).

Despite the existence of maximum acceptable limits for daily human intake in national and international laws, there is still no specific legislation regarding the safe limits of food dyes for the discharge of effluents into water bodies aiming at aquatic life protection. Studies have indicated that approximately $12 \%$ of the synthetic dyes are lost during manufacturing and processing operations (ANUNCIAÇÃO et al., 2015), which is one of the industrial sectors with increasing development. In 2019, according to the Brazilian Food Industry Association (ABIA), there was a $2.3 \%$ growth with revenues of approximately $\$ 700$ billion.

Currently, in the state of São Paulo, regulation 333/2012 prohibits the release of dyes in rivers, lakes, dams, and other freshwater bodies without proper treatment. It includes the dyes as contaminating substances that, thus, contribute to a greater control over water quality and public health (ALSP - regulation 333/2012).

According to those pieces of information, the present paper intends, through literature data, to evaluate whether the conditions and limits of use established for the tartrazine yellow dye are safe for aquatic environments. Therefore, we intend to answer:

- the relationship between the human use of this dye and the impact on aquatic environments;

- safe exposure concentrations in the literature for aquatic life protection that can be used as a basis;

- main biological effects to test organisms.

This review aimed to contribute to further clarification on the interactions between tartrazine yellow food coloring and humans, as well as between tartrazine and aquatic life. 


\section{Methodology}

A review was carried out using the PubMed database (National Library of Medicine of the United States) and CAPES journals (Coordination for the Improvement of Higher Education Personnel), in the period from 2010 to 2020 . We were interested in the effects of tartrazine on both humans and aquatic life. The keywords "toxicity" and "tartrazine food" were used for analyzing their impacts on humans, whereas for aquatic life, we applied: "ecotoxicology", "tartrazine food", "ecotoxicology", "tartrazine dye" and "ecotoxicology", "tartrazine dye", "zebrafish". The searches returned 235 papers, of which only four were on aquatic life. The 231 papers on humans were analyzed to investigate selection criteria and were eliminated if they:

- dealt only with dye degradation;

- analyzed other dyes simultaneously, which could imply in synergistic processes;

- used food to analyze the toxicity (this is because foods rarely contain only one color and many foods contain other forms of additives that would require further study);

- toxicity was not significant or doubtful.

\section{Composition and chemical structure of the tartrazine yellow dye}

Tartrazine yellow is a regulated artificial organic dye used by several industrial segments. It is prepared from diazotization of 4 - amino benzene acid with nitric acid and sodium nitrite. The diazo compound is coupled with 4,5-dihydro-5-oxo-1-(4-sulfophenyl)-1H-pyrazole-3carboxylic acid, methyl ester, ethyl ester or a salt of carboxylic acid, which is isolated and purified as the sodium or calcium salt (FOOD AND DRUG ADMINISTRATION, 2019). As the main non-colored component, it is possible to find sodium chloride and/or sodium sulfate in its composition.

The purity degree of the dye should not be less than $85 \%$ in its total color components (calculated as sodium salt), and the remain- ing $15 \%$ could be composed of sodium chloride or sodium sulfate (which is never explicitly mentioned by the FDA, 2019). The water-insoluble matter must not exceed $0.2 \%$ and the subsidiary coloring, no more than $1.0 \%$ with $0.5 \%$ of organic compounds (hydrazobenzene 4-aminobenzene-1-sulfonic acid, 5-oxo-1-(4-sulphophenyl)-2-pyrazoline-3-carboxylic acid, 4,4区-diazoaminobenzene (benzene sulfonic acid), tetrahydroxy succinic acid). Non-sulfonated primary aromatic amines can be present at levels of $\leq 0.01 \%$ (calculated as aniline), which were originated in the manufacturing process.

In the manufacturing process of the dye, impurities can reach $10 \%$ in the final compound (RESENDE, 2015) and many of them are metals, 4-aminobiphenyl, 4-aminoazobezene (sulfanilic acid) and benzidine (aromatic amine, formed by the oxidation of aniline). In the process of benzidine diazotization, a small part remains as free bendizine, but the majority remains in the form of subsidiary dyes, such as the diazo benzidine T-pyrazolone dye (Figure 1). According to Prival, Peiperl and Bell (1993) and Davis and Bailey Jr. (1993), if these compounds are present in the dye and mammals consume it, they will be reduced in the intestine, releasing benzidine in its free form. Compounds like benzidine are considered mutagenic and/or carcinogenic, since the electrolytes interact with DNA through their metabolism and induce mutations or generate tumors (MATHUR; BHATNAGAR; SHARMA, 2012).

The high solubility of this dye is due to the azo bond to two sulfonic groups, in addition to the functional carboxylic acid group (ALSHABIB et al., 2017). They have a high standard of fixation, resistance to light and humidity, and $\mathrm{pH}$ and oxygen variations (HUNGER, 2003; SHORE, 2002; ZOLLINGER, 1991). The dye can be identified through ultraviolet-visible spectrophotometry (UV-Vis), with a wavelength close to $426 \mathrm{~nm}$ (PARLAMENTO EUROPEU, 1995). This characteristic occurs due to the presence of chromophores, carboxylic, nitro, hydroxy and amino groups that can increase the specific absorption intensity (DEL GIOVINE; BOCCA, 2003) (Figure 1).

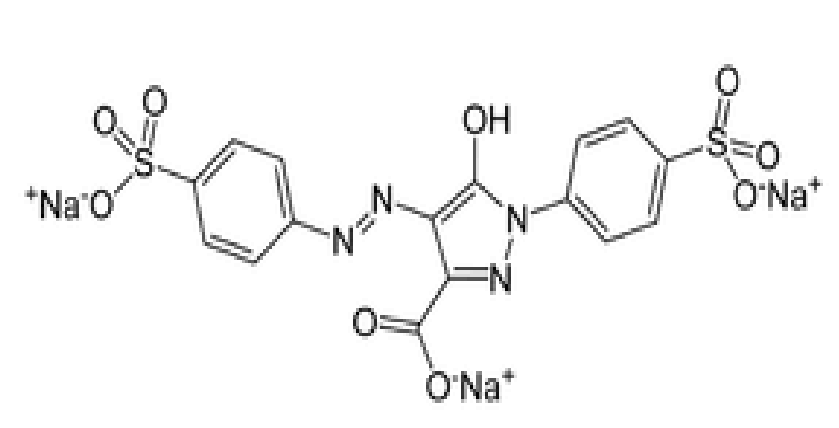

Figure 1 - Structure of the tartrazine yellow azo dye.

Source: Prado and Godoy (2003) and Cosmoquímica Indústria e Comércio LTDA (2009).
Usual name: Tartrazine yellow.

Chemical Name: Trisodium salt 4,5-dihydro-5-oxo-1 (4-sulfophenyl) -4[4-sulfophenyl-azo] -1H-pyrazol-3-carboxylate.

Synonyms: Tartrazine; FD \& C Yellow No. 5, Food Yellow No.4. Class: Monoazo.

Molecular Formula: C16H9N4Na3O = S2.

Molar Mass: 534, 35781. CAS: 1934-21-0.

Number Color Index: (C.I.) 19140.

Maximum Absorption $\lambda$ max. $=426 \mathrm{~nm}$.

Solubility in water: $38 \mathrm{mg} / \mathrm{L}$ at $2^{\circ} \mathrm{C}, 200 \mathrm{mg} / \mathrm{L}$ at $25^{\circ} \mathrm{C}$. LD 50 -

$2,000 \mathrm{mg} / \mathrm{kg}$, in mice (at this dosage, research has shown genotoxic damage). 


\section{Regulations on the use of tartrazine yellow dye} Human food

In 1943, the United Nations Conference on Agriculture and Food created the United Nations Food and Agriculture Organization (FAO). In 1948, it formed the first group of experts with responsibilities on human health to establish food standards, the FAO/World Health Organization - WHO, which promoted the creation of the JECFA in 1956 to:

- assess the risks of consumption by animals and humans;

- assign functional classes;

- check the identity and purity specifications;

- evaluate methods of analyses and develop standards or codes, such as labeling.

In 1961, the FAO and WHO created the Codex Alimentarius (CA) in an attempt to establish an international standard for the use of these additives. CA also resulted in the formation of the Codex Committee on Food Additives (CCFA), a group specialized only in food additives that establishes the maximum permitted levels of these products and acts together with the JECFA.

In 1989, CA from the FAO/WHO created the International Numbering System (INS), with the purpose of providing an international numbering system for identifying additives in lists of food ingredients and for using the specific name of the additive (name of color index $\mathrm{CI}$ ), based on the identification number (CI). The INS does not require toxicological approval of the substance.

In 2001, the European Food Safety Authority (EFSA) was created, providing independent scientific advice on the food-related risks, which can be existent or still emerging.

The JECFA guides the FAO and WHO on the use of food dyes, and this committee meets every two years to assess, among other demands concerning food, food additives.

In Brazil, the National Health Surveillance Agency (ANVISA) is the agency responsible for regulating the use of dyes, based on the principles of risk analyses of EFSA. ANVISA establishes the maximum limits and types of foods in which dyes can be applied without offering risk to human health. The organization also carries out surveillance activities through the Standing Committee on Food Additives - CPAA (FÁVERO; RIBEIRO; AQUINO, 2011).

In 1999, ANVISA, through Resolutions 382 (BRASIL, 1999a) to 389 (BRASIL, 1999e) of 5 August, determined the permission of only 11 artificial colors in Brazil, including the tartrazine yellow dye, which must, mandatorily, have its name declared in full on the labels of the products (Resolution No. 340 of 12/13/2002 - ANVISA/Brazilian Department of Health). The additive is listed in Appendix III of Resolution 04/88 from the National Health Council, Brazilian Department of health (BRASIL, 1988), which allows its use in food following the acceptable daily intake of $7.5 \mathrm{mg} / \mathrm{kg}$ per body weight (JECFA). Therefore, a 30-kg child can consume up to $225 \mathrm{mg}$ of tartrazine per day and a $60-\mathrm{kg}$ adult can consume up to $450 \mathrm{mg}$ per day of the dye without a probable health risk.

In 2009, ANVISA adapted the Mercosur Group Technical Resolution GMC n. 11/2006 on food additives within the scope of Mercosur (BRASIL, 2009).

ANVISA, through Resolution No. 285/2019 (BRASIL, 2019) on May 22, 2019, prohibited the use of food additives containing tartrazine and aluminum lacquer. Lacquers are preparations of salt from the dye (Resolution No. 37 of 1977 - BRASIL, 1977). It is a combination with the basic radical of aluminum, calcium and/ or sodium, which can be sold under the name aluminum, calcium and/or sodium lacquer. They are used on confectionery surfaces, processed cheeses, melted cheeses, soups, chemical yeast present in flours, pastries and pizza doughs, as well as bread and cookies, among many other food products.

\section{Regulation for discharge of effluents with dyes}

Synthetic dyes are added in the category of emerging pollutants, which are defined as any chemical substance that has not been included in monitoring programs, nor in legislation relevant to environmental quality, but is constantly being introduced into the environment due to anthropic activities (HORVAT et al., 2012).

Synthetic organic dyes, most of which are recalcitrant, are used universally in different manufacturing processes. The dyes are released into the environment in industrial effluents and are highly visible even at low concentrations ( $<1 \mathrm{mg} / \mathrm{L}$ ) (ALMEIDA et al., 2004).

The determination of color in liquid samples is based on the methodology proposed in the Standard Methods by the American Water Works Association (AWWA, 2005), whose principle is the determination of the color spectrophotometrically in a wavelength range between 450 and $465 \mathrm{~nm}$, using a standard solution of platinum-cobalt (Pt-Co). However, effluents whose colorations of the samples are very intense, hinder the satisfactory application of the method, and in practice, they are diluted to samples with strong colors so that they can be measured on the curve scale standard of 0.005 and $0.8 \%$ of absorbance of light at predefined wavelengths - Abs (AWWA, 2005). In addition, different dyes with equal concentrations can visually present different color intensities or even completely different shades (BELTRAME, 2006).

As to Brazil, there is still no specific legislation that defines color standards for effluents. However, in CONAMA 357/2005 (BRASIL, 2005), on articles 15-III and 16-I, it is understood that, in the absence of defined standards, one should adopt those available for the class in which the receiving bodies are included. Thus, for freshwater bodies classified as Classes 2 and 3, the tolerable value of real or true color would be up to $75 \mathrm{mg} \mathrm{Pt} / \mathrm{L}$ (platinum scale per liter). CONAMA 430/11, in its article 18, shows that effluents of any nature should not have the potential to cause toxicity in the aquatic biota. 


\section{Tartrazine toxicity}

Toxicity assessment by the Joint Expert Committee on Food Additives Commission

The tartrazine yellow dye was first evaluated in 1966 by JECFA experts in food additives, and later in 1975 and 1984 by the Scientific Committee for Food (SCF), when the value of the IDA was set at 7.5 $\mathrm{mg} / \mathrm{kg} / \mathrm{pc} /$ day for humans. In a more recent meeting (WHO, 2017), the committee reassessed this value, analyzing some research produced in recent years.

The committee considered that toxicological research in recent years is insufficient to alter the value of the IDA, considering that tartrazine is not highly toxic. The analyses considered three studies as a toxicity parameter: Sasaki et al. (2002), who described an LD50 value greater than 2,000 mg/kg/pc/day in studies with mice; Borzelleca and Hallagan (1988a), performed with mice for 104 weeks, in which the unobserved adverse effect level (NOAEL) of $9735 \mathrm{mg} / \mathrm{kg} / \mathrm{pc} /$ day was established, and Borzelleca and Hallagan (1988b), with rats at maximum exposure of 125 weeks, in which the NOAEL of 2,641 and 3,348 $\mathrm{mg} / \mathrm{kg} /$ day were established.

A study by Axon et al. (2012) concluded that the dye can act as an activator of estrogen receptors (xenoestrogen), increasing the risk of primary biliary complications and cirrhosis in postmenopausal women. However, according to the committee's evaluation, it is unlikely that cosumption could reach the levels of exposure (220 and $160 \mathrm{nM}$ ) used in the research.

Research by Patterson and Butler (1982) reported significant increase in chromosomal aberrations in fibroblastic cells of Muntiacus muntjak in vitro (5 to $20 \mu \mathrm{g} / \mathrm{mL}$ ), but it did not report cytotoxicity.

Maekawa et al. (1987) studied concentrations of 0,1 or $2 \%$ administered in rats that were statistically significant, presenting mesothelioma in the abdominal cavity in males and stromal polyps of the endometrium in females, but the incidence of these tumors was not dose-dependent and was within the historical control range for these tumors and within this strain of mice.

Mpountoukas et al. (2010) studied human peripheral blood cells in concentrations of 0.02 and $8 \mathrm{mM}$ and did not find genotoxicity, but there was cytotoxicity (which can cause cell death) in high concentrations (4.0 and $8.0 \mathrm{mM}$ ), and the dye also demonstrated ability to bind to DNA.

Tartrazine would have the ability to bind to human and bovine serum albumin, forming a complex with these proteins, potentially limiting their physiology and function (PAN et al., 2011). However, it is poorly absorbed, and this effect would probably not have an important role; only in case of greater exposure or association with other dyes or drugs capable of binding to plasma or proteins.

Toxicity research in rats showed significant changes in some blood parameters that indicate liver and kidney malfunction (ABOEL-ZAHAB et al., 1997; MOUTINHO; BERTGES; ASSIS, 2007; AMIN; HAMEID II; ELSTTAR, 2010; EL-WAHAB; MORAM,
2013; GHONIMI; ELBAZ, 2015). However, the daily intake of 8,103 and $9,735 \mathrm{mg} / \mathrm{kg} /$ day in males and females, respectively, for 104 weeks, resulted in no adverse effects (BORZELLECA; HALLAGAN, 1988b).

Another issue raised by the commission was the difficulties in the toxicity analyses of the tartrazine dye when studied in mixture with other dyes (GIRI et al., 1990; POLLOCK; WARNER, 1990; COLLINS et al., 1990; 1992; ABOEL-ZAHAB et al., 1997; SASAKI et al., 2002; MCCANN et al., 2007; ELHKIM et al., 2007; AXON et al., 2012; EL-WAHAB; MORAM, 2013; CEYHAN et al., 2013; SAXENA; SHARMA, 2014; 2015; ERICKSON; FALKENBERG; METZ, 2014), due to the interactions that can occur between chemical substances.

The committee criticized the relevance of some in vitro genotoxicity tests because the azo linkage and desulfonation in the tested metabolic products were not broken. They have also noted that the potential for tartrazine to cause mutations is in occasional cases, which, if present, would be directed to cells lining the intestine during the transit of metabolites before excretion in feces. The committee cites a personalized protocol for the reverse mutation assay, using flavin mononucleotides to accelerate azo-reduction in hamsters, with a lesser tendency to inactivate azo-reduction products, which produced negative results (PRIVAL; MITCHELL, 1982; PRIVAL et al., 1988).

In assessing the reproductive parameters and offspring development, the Committee's report cites again the paper of Borzelleca and Hallagan (1988a; 1988b). It concluded that the administration of 2,641 and $3,348 \mathrm{mg} / \mathrm{kg} / \mathrm{pc} /$ day did not affect the reproduction of rats. Tanaka (2006) also found no neurotoxic effects after providing doses of 83,259 , and $773 \mathrm{mg} / \mathrm{kg}$ /day during five to nine weeks to F0 and $\mathrm{F} 1$ rat lineages.

Neurological studies, in juvenile mice and rats that received tartrazine orally at doses of up to $700 \mathrm{mg} / \mathrm{kg} / \mathrm{pc} /$ day for 30 days, revealed some neurobehavioral and neurochemical effects (GAO et al., 2011). The committee, however, noted that only a small number of animals per group/dose was used and in very high doses, which prevented the use of these studies for evaluation. Ceyhan et al. (2013) administered tartrazine with an IDA dye mixture $(7.5 \mathrm{mg} / \mathrm{kg} / \mathrm{pc} /$ day $)$ in female rats, before and during pregnancy, but no effects on reproductive parameters were observed.

Collins et al. $(1990 ; 1992)$ administered doses of $60,100,200$, 400,600 , and $1,000 \mathrm{mg} / \mathrm{kg} / \mathrm{pc} /$ day in pregnant rats from 0 to 19 days of gestation, but no maternal toxicity or dose-related effects prevented fetal development. Subsequently, the dye was administered to rats throughout the gestational phase in doses of $0.5 ; 0.1$; $0.2 ; 0.4 ; 0.7 \%$ diluted in drinking water and $67.4 ; 131.8 ; 292.4 ; 567.9$ and $1064.3 \mathrm{mg} / \mathrm{kg} / \mathrm{pc} /$ day in food, and there were also no changes in viability, size, weight, or teratogenic effects on fetal development. 
In humans, many reports concluded that the tartrazine yellow dye causes intolerance or hypersensitivity reactions. However, the reports analyzed by the committee were of foods consumed by the population, which rarely contain only the dye, but a mixture of dyes. In the study carried out by Elhkim et al. (2007), these symptoms were observed in only $0.12 \%$ of the analyzed population, which was considered poorly relevant by the committee.

Based on studies associating the consumption of food and drinks containing tartrazine with hyperactivity in children (POLLOCK; WARNER, 1990; BATEMAN et al., 2004; MCCANN et al., 2007; STEVENSON et al., 2010), the committee warned about the presence of the substance sodium benzoate in these products. However, these studies were considered limited due to inconsistencies in the conclusions and use of mixtures of food dyes.

JECFA (WHO, 2017) gathered studies on the exposure to food with tartrazine carried out in the European Union (EFSA, 2009); United States (DOELL et al., 2015; IACM, 2015); Australia (FSANZ, 2012); France (ELHKIM et al., 2007); Ireland (CONNOLLY et al., 2010); Hong Kong (LOK et al., 2010); India (DIXIT et al., 2011); Indonesia (FIRDAUS; ANDARWULAN; HARIYADI, 2011), and South Korea (SUH; CHOI, 2012; HA et al., 2013). These studies were performed using various concentrations and followed the dietary culture of each country. EFSA concluded that the maximum exposure for children aged 1 to 10 years should be 0.4 to $7.3 \mathrm{mg} / \mathrm{kg} / \mathrm{day}$, and exposure to tartrazine by the population, in general, does not present a health concern.

\section{Evaluation of tartrazine ecotoxicity}

Dyes have a high organic load that, in many cases, depletes dissolved oxygen and causes changes in the biological community. Its presence in water bodies affects from microalgae, which are the base of the aquatic food chain, to the top trophic level, humans. The accumulation of algae can cause eutrophication, a phenomenon that occurs when the environment receives higher concentrations of nutrients, mainly nitrogen (present in the chemical constitution of azo dyes such as nitrogen, nitrites, and nitrates), and excessive increases in algae and cyanobacteria may release toxins (MATSUZAKI; MUCCI; ROCHA, 2004).

There is little ecotoxicological research with the tartrazine yellow dye, except for those by Joshi and Katti (2017) that present values of CENO and CL50, and Jiang et al. (2020) that present LC50 values for the species D. rerio. In this context, Silva and Fracácio (2020) studied the development of $D$. rerio embryos and larvae in concentrations of 0.05 and 0.5 g.L.- of analytican tartrazine (100\%), and commercial standard of $86 \%$ and at a concentration of $0.05 \mathrm{mg} . \mathrm{L}^{-1}$. They observed loss of viability of the eggs after 24 hours of fertilization, and from 48 to $72 \mathrm{hpf}$ there were no hatching and deformities, such as edema of the yolk sac, cardiac edema, distortion of the tail, lack of pigmentation and decreased heart rate, indicating ecotoxicity at the said concentrations. This paper shows ecotoxicological effects in concentrations below those presented by other papers available in the literature.

\section{Results}

Analyses of toxicological literature

After the application of the manuscript selection criteria, 29 articles were considered, in which four of them were on ecotoxicology.

The biggest concern regarding the use of tartrazine azo dye is its reduction to aromatic amines (DEMIRKOL; ZHANG; ERCAL, 2012). This mechanism is responsible for several disorders, such as anemia, pathological lesions in the brain, liver, kidney and spleen, in addition to allergic reactions, tumors, and cancer. Changes in serum albumin in humans also compromise biological functions (PAN et al., 2011). In molecular toxicology studies, tartrazine has bound to the central hemoglobin cavity (BASU; KUMAR, 2016a).

Liver enzymes increased in rats administered with tartrazine, suggesting lesions and impairment of liver cells, cytoplasm, and mitochondrial organelles (AMIN; HAMEID II; ELSTTAR, 2010; HIMRI et al., 2011; KHAYYAT et al., 2017).

In reproductions, tartrazine induced a marked deficiency in antioxidant biomarkers (SOD, catalase and GSH) in groups of young male rats (MOHAMED; GALAL; ELEWA, 2015). Tartrazine also induced adverse effects on the memory and learning of rats (GAO et al., 2011), hyperactivity, antisocial behavior, and anxiety in male rats (KAMEL; EL-LETHEY, 2011).

The largest number of studies regarding dye toxicity was carried out with rats (13 papers); cellular components or blood of human beings (four papers); mice (three papers); hamster (one paper) and others such as Allium cepa, calves, and horses (four papers covering these groups), as seen in Table 1 .

\section{Ecotoxicological analyses}

In the bibliographic survey we found papers with the fish $D$. rerio exposed in different phases to varied concentrations of the tartrazine yellow dye. Joshi and Katti (2017) found a value of the unobserved effect concentration (CENO) and lethal concentration (CL (I) 50, 96 h) of $5\left(2.67 \mathrm{gL}^{-1}\right)$ and $29.4 \mathrm{mM}$, respectively $\left(15.7 \mathrm{gL}^{-1}\right)$. Jiang et al. (2020) found the CL (I) 50, $96 \mathrm{~h}$ value of $47.10 \mathrm{mM}\left(25.1 \mathrm{~g} . \mathrm{L}^{-1}\right)$. Of these papers, those of Gupta et al. (2019) and Silva and Fracácio (2020) described deformities that were found in the embryonic and larval development of $D$. rerio, suggesting that the tartrazine dye, once released into the aquatic environment, compromises aquatic life (Table 2).

\section{Discussion}

According to the literature, the tartrazine yellow dye can cause toxicity to humans in dosages considered safe, in periods of prolonged exposure. Dosages below that recommended for IDA demonstrated the ability to damage liver and kidney tissues in fetuses, in addition to other changes described (Table 1), depending on the time of exposure.

The reduction of dye into aromatic amines and benzene compounds in the digestive system of rats can trigger anemia, pathological lesions in the brain, liver, kidney and spleen, in addition to aller- 
Table 1 - Research carried out in the last ten years with the tartrazine yellow dye that resulted in toxicity.

\begin{tabular}{|c|c|c|c|}
\hline Author (s) & Objectives & Dose & Conclusions \\
\hline $\begin{array}{l}\text { Amin, Hameid } \\
\text { II and Elsttar } \\
(2010)\end{array}$ & $\begin{array}{l}\text { To evaluate the toxic effects } \\
\text { of tartrazine dye, using } \\
\text { biomarkers of oxidative } \\
\text { stress in the kidney and } \\
\text { liver of rats. }\end{array}$ & $\begin{array}{l}15 \text { and } 500 \mathrm{mg} / \mathrm{kg} / \mathrm{pc} / \mathrm{day} \text {, in } \\
\text { rats (Rattus norvegicus) for } \\
30 \text { days. }\end{array}$ & $\begin{array}{l}\text { - Blood and enzymatic changes } \bullet \text { Significant weight loss } \\
\text { - Reduction of liver antioxidants } \bullet \text { Increased oxidative stress } \\
\text { - Decreased activity of superoxide dismutase (a cellular } \\
\text { antioxidant enzyme). }\end{array}$ \\
\hline
\end{tabular}

Morais

(2010)

\section{To evaluate the toxic effects} of tartrazine dye in people with respiratory problems and sensitivity to non-steroidal anti-inflammatory drugs. To evaluate the toxic effects Mpountoukas of tartrazine dye in human et al. (2010) peripheral blood cells with the dye.

To evaluate the toxic effect

Gao et al. of tartrazine on learning and memory functions in mice and rats.

To address the influence of different doses of

Kamel and El- tartrazine exposure to levels Lethey (2011) of hyperactivity, anxiety, depression, and antisocial behaviors in rats.

Kashanian and Zeidali

(2011) To address DNA interactions of the cells of a calf's thymus and its interaction with tartrazine.

Pan et al. To test the molecular link (2011) between plasma albumin and tartrazine.

Himri et al. (2011)

To address oral toxicity in Wistar rats.

To evaluate changes in oxidative stress parameters, Demirkol, such as glutathione (GSH), Zhang and malondialdehyde (MDA), Ercal (2012) glutathione peroxidase. Activity (GPx) and catalase (CAT) in hamster ovary cells.

Gomes et al. To address cytotoxic effect (2013) of tartrazine on the cell cycle of Allium cepa L.
Doses of 5, 10, and $20 \mathrm{mg}$ of

the additive in 77 subjects for seven days.

\subsection{2 to $8.0 \mathrm{mM}$}

(0.01 and 4.27 g.L- 1$)$ in vitro peripheral blood cells (for 72 hours).

Kun ming mice and Sprague dawley 175,350 and rats $700 \mathrm{mg} / \mathrm{kg}$ of tartrazine by body weight once daily for 30 days per gavage.

0,1 and $2.5 \%$ administered to male Wistar rats for 16 weeks.

$10 \mathrm{nM}$ of the dye

Human albumin and bovine albumin at concentrations of $5.0 \times 10^{-5} \mathrm{~mol} . \mathrm{L}^{-1}$ and tartrazine at concentrations of $1.0 \times 10^{-5} \mathrm{~mol} . \mathrm{L}^{-1}$ $7.5 ; 10 \mathrm{mg} / \mathrm{kg} / \mathrm{pc} /$ day with $3.75 \mathrm{mg} / \mathrm{kg} / \mathrm{pc} /$ day of sulphanilic acid.

Chinese hamster cells $(\mathrm{CHO})$ $\left(10 \times 10^{3}\right.$ cells $)$ exposed in tartrazine concentrations of $10,100,500,1,000,2,000 \mu \mathrm{M}$ $(5.34 ; 53,43 ; 267.15 ; 534.3$; 1068 g.L.-1 $-3,8,12$ and 24 h).

0.4 and $4.0 \mathrm{~mL}$ in Allium cepa $\mathrm{L}$ roots, in 24 - and 48 hour exposures.
- Reduction in peak expiratory flow; itchy skin and hives; - Immune system reactions affecting the skin and airways.

- The dye changed the rates of mitotic division at high concentrations (4.0 and $8.0 \mathrm{mM}$ ); • High cytotoxicity (that can cause cell death); • The dye also demonstrated its ability to bind to DNA.

- Oxidative damage to the brain; • Decline in catalase, glutathione activities; peroxidase (GSH-Px) and superoxide dismutase (SOD); • Increase in the level of malonaldehyde (MDA), which resulted in adverse effects on learning and memory functions that can be attributed to the increase in lipid peroxidation products and reactive oxygen species, inhibiting antioxidant defense enzymes.

- Tartrazine-treated rats showed hyperactivity; • The anxiogenic effect of tartrazine was evident; • Ingestion of tartrazine promoted significant depression, expressed by prolonged immobilization during forced swim test; $\bullet$ Compromised social interaction.

- The DNA - tartrazine interaction affected the helical structure of the DNA, in addition to showing an easier connection between tartrazine and denatured DNA. The DNA bound to the dye underwent changes.

- Tartrazine can bind to albumin spontaneously and form a complex, with Van der Walls bonds and hydrogen bonds; • Tartrazine alters the conformation of the protein.

- Liver increased by $10 \mathrm{mg} / \mathrm{kg} / \mathrm{pc} /$ day;

- Changes in the kidneys; - In high doses, tartrazine can induce oxidative stress through the formation of free radicals.

- Depletion of GSH (one of the main antioxidant cells), causing oxidative stress (that plays an important role in sclerosis, chronic lung disorders, paralysis, rheumatoid arthritis, age-related degenerations, and Alzheimer's disease).

- Mitotic analyzes of the doses and exposure times evaluated were cytotoxic to the cells. 
Table 1 - Continuation

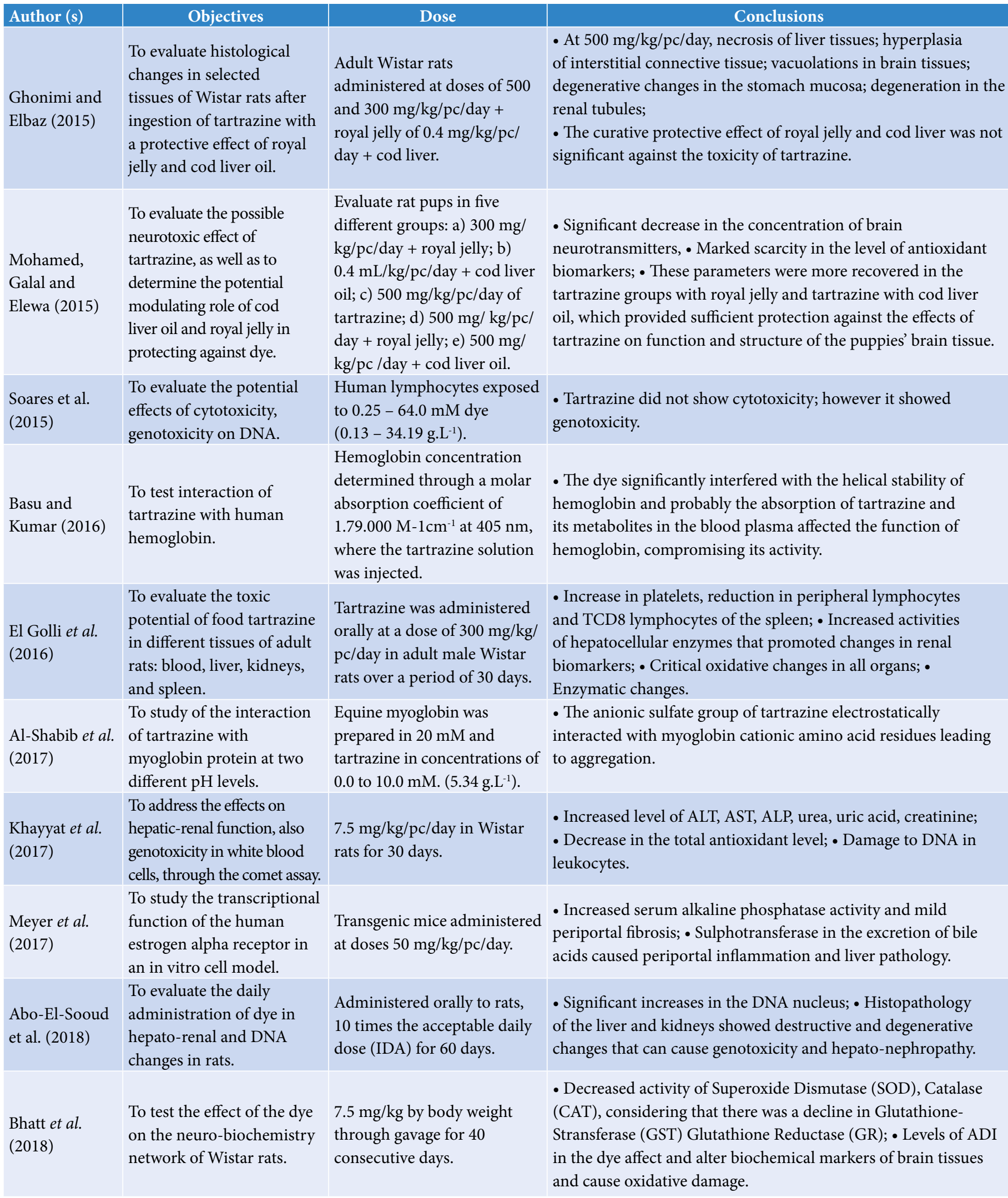


Table 1 - Continuation

\begin{tabular}{|c|c|c|c|}
\hline Author (s) & Objectives & Dose & Conclusions \\
\hline $\begin{array}{l}\text { Floriano et al. } \\
(2018)\end{array}$ & $\begin{array}{l}\text { To evaluate the cytotoxicity } \\
\text { and genotoxicity of } \\
\text { tartrazine in human } \\
\text { leukocyte culture. }\end{array}$ & $\begin{array}{l}\text { Concentrations of } 5,17.5 \text {, } \\
35,70,100,200,300,400, \\
\text { and } 500 \mu \mathrm{g} \mathrm{mL} L^{-1} \text { in leukocyte } \\
\text { cultures. }\end{array}$ & $\begin{array}{l}\text { - At a concentration of } 70 \mu \mathrm{g} \mathrm{mL}^{-1} \text {, the dye induced DNA } \\
\text { damage. }\end{array}$ \\
\hline $\begin{array}{l}\text { Abd-Elhakim } \\
\text { et al. (2019) }\end{array}$ & $\begin{array}{l}\text { To study the fibrogenic } \\
\text { fibers of rats triggered by } \\
\text { tartrazine, through tests } \\
\text { with dye and chlorophyll. }\end{array}$ & $\begin{array}{l}\text { The rats were administered } \\
\text { ten times the acceptable } \\
\text { daily intake of tartrazine } \\
\text { or chlorophyll for } 90 \\
\text { consecutive days. }\end{array}$ & $\begin{array}{l}\text { - Increase in mRNA and immunohistochemical localization of } \\
\text { renal fibrotic markers and liver collagen; • Differences in AST, } \\
\text { ALP, creatinine, and urea levels; • Decline in SOD, CAT and GSH } \\
\text { enzymes in kidney and liver. }\end{array}$ \\
\hline $\begin{array}{l}\text { Hashem et al. } \\
\text { (2019) }\end{array}$ & $\begin{array}{l}\text { To determine the effect } \\
\text { of tartrazine dye on fetal } \\
\text { development. }\end{array}$ & $\begin{array}{l}\text { Daily administration of } \\
0.45 \text { and } 4.5 \mathrm{mg} / \mathrm{kg} / \mathrm{pc} / \\
\text { day tartrazine, in the fetal } \\
\text { development of Wistar rats } \\
\text { from the } 6^{\text {th }} \text { to the } 15^{\text {th }} \text { day of } \\
\text { gestation. }\end{array}$ & $\begin{array}{l}\bullet \text { Liver damage; } \bullet \text { Destroyed and necrotic renal tubules; } \bullet \text { Absent } \\
\text { coccygeal vertebrae; } \bullet \text { Absence of hind limbs; • Irregular ribs. }\end{array}$ \\
\hline $\begin{array}{l}\text { Albasher et al. } \\
(2020)\end{array}$ & $\begin{array}{l}\text { To evaluate perinatal } \\
\text { exposure of the dye in doses } \\
\text { within the IDA range in } \\
\text { mice, with an emphasis on } \\
\text { neuro behavioral changes } \\
\text { and redox imbalance. }\end{array}$ & $\begin{array}{l}\text { Pregnant female mice } \\
\text { received tartrazine; after } \\
\text { birth, at } 21 \text { and } 35 \text { days, the } \\
\text { mice were sacrificed and } \\
\text { histological analyzes were } \\
\text { performed. }\end{array}$ & $\begin{array}{l}\text { - Lipid peroxidation and decreased antioxidants in different } \\
\text { regions of the newborn's brain; • Increased hemoglobin, } \\
\text { erythrocytes, leukocytes, and platelets; • Altered locomotor } \\
\text { behavior as a reflex of anxiety; • Oxidative stress. }\end{array}$ \\
\hline
\end{tabular}

gic reactions, tumor, and cancer. Changes in serum albumin cause decreased production and malabsorption of proteins, cirrhosis, and higher liver enzymes, which compromise cells and the work of mitochondria, leading to an imbalance of oxidative stress and presence of free radicals that cause cytogenicity. The dye was able to interact with DNA, triggering mutations.

Ingestion of the dye also worsens symptoms in patients with allergic reactions, bronchial asthma, hives, and behavioral changes such as attention deficit and hyperactivity in children. Tartrazine also induced adverse effects on memory, learning and behavioral changes in rats and fish.

Research with $D$. rerio has shown that the additive alters physiological functions, not only by ingestion, but also at constant exposures, as is the case in aquatic environments. Regarding the ecotoxicity of the tartrazine yellow dye, data from Joshi and Katti (2017) indicated a CENO value of $5 \mathrm{mM}$, equivalent to a concentration of $2.67 \mathrm{~g} / \mathrm{L}-1$, in seven-day tests with $D$. rerio embryos. However, it is worth mentioning that the eggs of this species present the chorion, an acellular membrane that surrounds the embryo until the moment of its hatching, which occurs at $72 \mathrm{hpf}$ (hours after fertilization). This structure has pores be- tween 0.5 and $0.7 \mathrm{~mm}$ in diameter and, in this way, partially isolates the embryo from the environment (MEDEIROS et al., 2017). Therefore, for this value to be considered safe, other stages of the species' development must be tested. The literature also reports that the chorion can be impervious to a good number of pollutants; however, studies have proven that the tartrazine yellow dye has overcome this protective barrier (JOSHI; KATTI, 2017; GUPTA et al., 2019; SILVA; FRACÁCIO, 2020), and the dye also accelerated the embryo hatch rates (from 72 hpf to $48 \mathrm{hpf}$ ).

In the absence of CENO, literature recommends using the lethal concentration value to $50 \%$ of the exposed population, at a given exposure time, and dividing it by 10 , as estimated safety values. Thus, the estimated CENO values would be 2.94 and $4.71 \mathrm{mM}$, corresponding to 1.57 and 2.51 g. $\mathrm{L}^{-1}$ respectively, which is close to the reported CENO values. However, data obtained by Silva and Fracácio (2020) show that in low concentrations, compared to the values reported, there was toxicity to larvae in 48 hours after hatching at a concentration of 0.05 g. $\mathrm{L}^{-1}$.

The concern with aquatic life protection lies in the fact that the dye can reach surface waters through large-scale production, with an 
Table 2 - Ecotoxicological research carried out in the last ten years with the tartrazine yellow dye that resulted in toxicity.

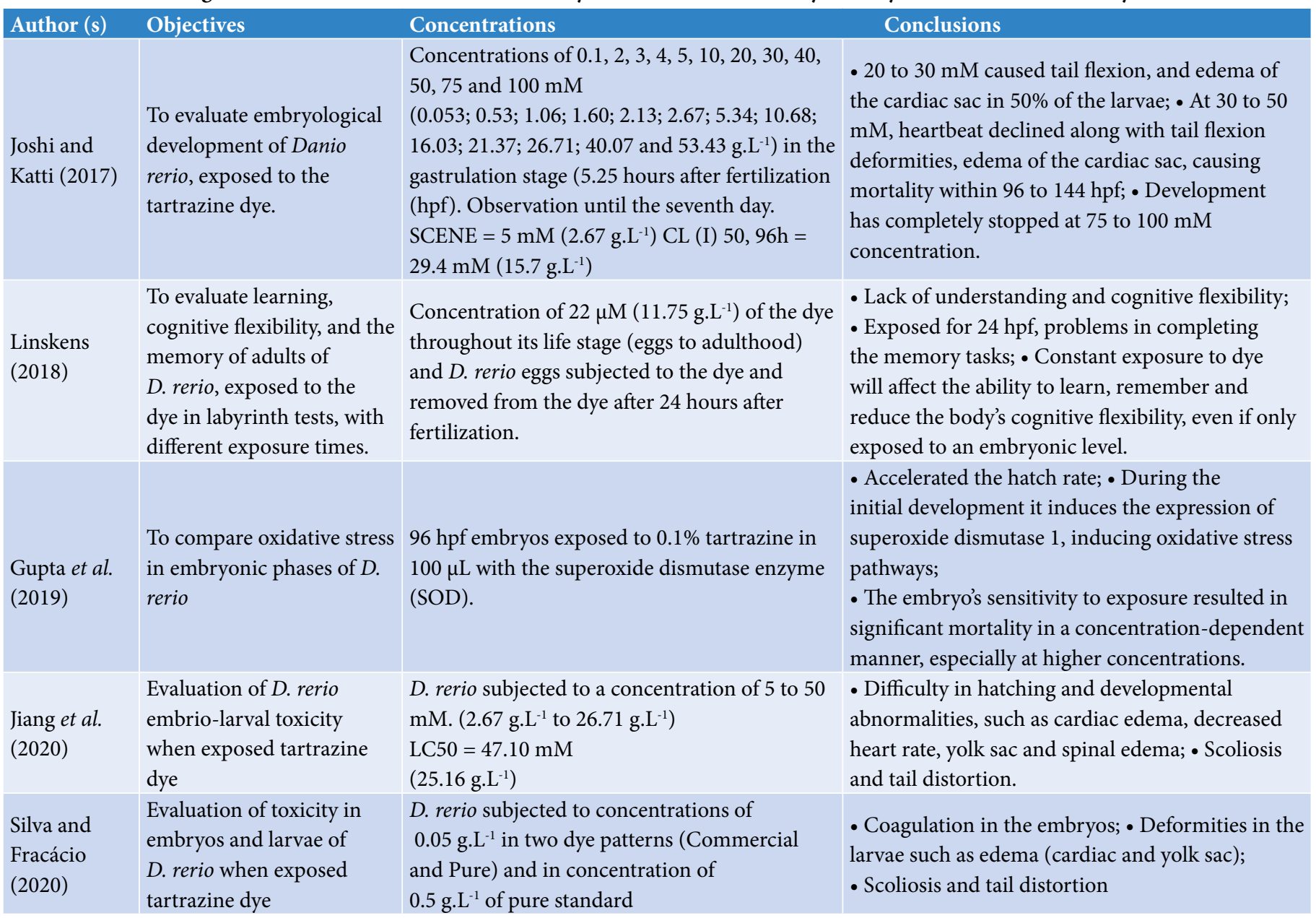

interaction between the consumption of these industrialized foods and the quality of aquatic ecosystems - a challenge for the coming years (TEIXEIRA; PORTO, 2008). Conventional effluent treatment systems cannot effectively degrade this type of dye due to its high stability, resistance to light, and moderate oxidizing agents. Many companies, due to the peculiar characteristics of their products, dilute the dyes to cause less color impact on the environment. The dye use should be limited to the smallest amount as possible to achieve the desired effect and only when there is no other alternative, considering the lack of adequate legislation and impacts they cause to the environment and human health.

\section{Conclusions}

- Tartrazine yellow food dye is toxic even at the dose indicated for acceptable daily intake for humans. In this sense, the laws that regulate the use of the additive in food should consider the new research on the molecular interactions of the dye with animal cells to review the doses considered safe;
- There is a direct relationship between the production and use of these dyes and aquatic ecotoxicity, through the release of effluents generated in water bodies. Without adequate treatments, these chemical compounds and their by-products cause risks to biota;

- The tartrazine yellow dye crosses the protective barrier of the chorion in $D$. rerio embryos and accelerates reproduction. However, studies with other stages of the life cycle of the referred species and with other species of different trophic levels are recommended;

- The Regulation 333/2012 of the state of São Paulo should serve as a model for other areas of the national territory, and greater attention should be given to the launch of food dyes, since the azocores are freely purchased and used commercially in the food industry. This economic sector is still in need of effective regulation and implies in environmental damage and risks to human health.

\section{Acknowledgements}

To Fundação de Amparo à Pesquisa do Estado de São Paulo (Fapesp). 


\section{Contribution of authors:}

Silva, J.: conceptualization, methodology, validation, formal analysis, investigation, writing - original draft. Fracácio, R.: resources, data curation, writing review \& editing, funding acquisition.

\section{References}

ABD-ELHAKIM, Y. M.; MOUSTAFA, G. G.; HASHEM, M. M., ALI H. A., ABO-EL-SOOUD, K.; EL-METWALLY, A. E. Influence of the long-term exposure to tartrazine and chlorophyll on the fibrogenic signalling pathway in liver and kidney of rats: the expression patterns of collagen $1-\alpha$, TGF $\beta-1$, fibronectin, and caspase-3 genes. Environmental Science and Pollution Research International, v. 26, n. 12, p. 12368-12378, 2019. https://doi.org/10.1007/ s11356-019-04734-w

ABO-EL-SOOUD, K. A.; HASHEM, M. M.; BADR, Y. A.; ELEIWA, M. M. E.; GAB-ALLAHA, A. Q.; ABD-ELHAKIM, Y. M.; BAHY-EL-DIEN, A. Assessment of hepato-renal damage and genotoxicity induced by long-term exposure to five permitted food additives in rats. Environmental Science and Pollution Research, v. 25, n. 26, p. 26341-26350, 2018. https://doi.org/10.1007/ s11356-018-2665-Z

ABOEL-ZAHAB, H.; EL-KHYAT, Z.; SIDHOM, G.; AWADALLAH, R.; ABDEL-AL, W.; MAHDY, K. Physiological effects of some synthetic food colouring additives on rats. Bollettino Chimico Farmaceutico, v. 136, n. 10, p. 615-627, 1997.

ALBASHER, G.; MAASHI, N.; ALFARRAJ, S.; ALMEER, R.; ALBRAHIM, T.; ALOTIBI, F.; BIN-JUMAH, M.; MAHMOUD, A. M. Perinatal Exposure to Tartrazine Triggers Oxidative Stress and Neurobehavioral Alterations in Mice Offspring. Antioxidants, v. 9, n. 1, p. 53, 2020. https://doi.org/10.3390/ antiox 9010053

ALMEIDA, E.; ASSALIN, M. R.; ROSA, M. A.; DURÁN, N. Tratamento de efluentes industriais por processos oxidativos na presença de ozônio. Química Nova, São Paulo, v. 27, n. 5, 2004. https://doi.org/10.1590/S010040422004000500023

AL-SHABIB, N. A.; KHAN, J. M.; KHAN, M. S.; ALI, M. S.; AL-SENAIDY, A. M.; ALSENAIDY, A. A.; HUSAIN, F. M.; HAMAD, A.; AL-LOHEDAN, H. M. Synthetic food additive dye "Tartrazine" triggers amorphousaggregation in cationic myoglobin. International Journal of Biological Macromolecules, v. 98, p. 277-286, 2017. https://doi.org/10.1016/j.ijbiomac.2017.01.097

AMERICAN WATER WORKS ASSOCIATION (AWWA). Standards Methods for Water Analisys. 21ª edition. Washington, D.C.: APHA, 2005.

AMIN, K. A.; HAMEID II, A.; ELSTTAR, A. H. A. Effect of food azo dyes tartrazine and carmoisine on biochemical parameters related to renal, hepatic function and oxidative stress biomarkers in young male rats. Food and Chemical Toxicology, v. 48, n. 10, p. 2994-2999, 2010. https://doi.org/10.1016/j. fct.2010.07.039

ANASTÁCIO, L. B.; OLIVEIRA, D. A.; DELMASCHIO, C. R.; ANTUNES, L. M. G.; CHEQUER, F. M. D. Corantes Alimentícios Amaranto, Eritrosina B e Tartrazina, e seus possíveis Efeitos Maléficos à Saúde Humana. Journal of Applied Pharmaceutical Sciences, v. 2, n. 3, p. 16-30, 2016.

ANUNCIAÇÃO, S. A.; ROCHA, G. H. A. M.; SILVA, G. O.; MARTINS, B. M.; BORGES, E. C. L., SÁ, F. P. Estudo da remoção do corante alimentício, vermelho 40, utilizando cacos de telhas, em função do ph. In: ENCONTRO
NACIONAL DE TECNOLOGIA QUÍMICA, 8., 2015, Vitória. Annals [...]. 2015.

ASSEMBLEIA LEGISLATIVA DO ESTADO DE SÃO PAULO. Projeto de Lei $n^{\circ} 333 / 2012$. Proíbe o lançamento direto nos rios, lagos, represas e demais corpos de água doce do Estado de São Paulo e determina a classificação dos corantes como contaminantes ambientais. São Paulo, 2012.

AXON, A.; MAY, F. E. B.; GAUGHAN, L. E.; WILLIAMS, F. M.; BLAIN, P. G.; MATTHEW, C.; WRIGHT, M. C. Tartrazine and sunset yellow are xenoestrogens in a new screening assay to identify modulators of human oestrogen receptor transcriptional activity. Toxicology, v. 298, n. 1-3, p. 40-51, 2012. https://doi.org/10.1016/j.tox.2012.04.014

BASU, A.; KUMA, G. S. Multispectroscopic and calorimetric studies on the binding of thefood colorant tartrazine with human hemoglobin. Journal of Hazardous Materials, v. 318, p. 468-476, 2016.

BATEMAN, B.; WARNER, J. O.; HUTCHINSON, E.; DEAN, T.; ROWLANDSON, P.; GANT, C.; GRUNDY, J.; FITZGERALD, C.; STEVENSON, J. The effects of a double blind, placebo controlled, artificial food colourings and benzoate preservative challenge on hyperactivity in a general population sample of preschool children. Archives of Disease in Childhood, Londres, v. 89, n. 6, p. 506-511, 2004. https://doi.org/10.1136/ adc. 2003.031435

BELTRAME, L. T. C. Sistemas Microemulsionados Aplicados à Remoção de Cor de efluentes têxteis. Thesis (Doctoring) - Universidade Federal do Rio Grande do Norte, Natal, 2006.

BHATT, D.; VYAS, K.; SINGH, S.; JOHN, J.; SONI, I. Tartrazine induced neurobiochemical alterations in rat brain sub-regions. Food and Chemical Toxicology, v. 113, p. 322-327, 2018. https://doi.org/10.1016/j.fct.2018.02.011

BORZELLECA, J. F.; HALLAGAN, J. B. A chronic toxicity/carcinogenicity study of FD\&C Yellow No. 5 (tartrazine) in mice. Food and Chemical Toxicology, v. 26, n. 3, p. 189-194, 1988a. https://doi.org/10.1016/02786915(88)90118-4

BORZELLECA, J. F.; HALLAGAN, J. B. Chronic toxicity/carcinogenicity studies of FD\&C Yellow No. 5 (tartrazine) in rats. Food and Chemical Toxicology, v. 26, n. 3, p. 179-187, 1988b. https://doi.org/10.1016/02786915(88)90117-2

BRASIL. Agência Nacional de Vigilância Sanitária (Anvisa). Conselho Nacional de Saúde. Resolução nº 04. Brasil: Ministério da Saúde, 24 nov. 1988.

BRASIL. Agência Nacional de Vigilância Sanitária (Anvisa). Informe Técnico $n^{\circ} 11$, de 26 de janeiro de 2006. Brasil: Agência de Vigilância Sanitária, 2006. Available at: <http://bvsms.saude.gov.br/bvs/saudelegis/anvisa/2006/ res0011_26_01_2006.html>. Accessed on: Feb. 5, 2020.

BRASIL. Agência Nacional de Vigilância Sanitária (Anvisa). Resolução nº 37, de 1977. Brasil: Agência Nacional de Vigilância Sanitária, 1977. Available at: <https:// www.mprj.mp.br/documents/20184/418559/res37.pdf >. Accessed on: Feb. 5, 2020. 
BRASIL. Agência Nacional de Vigilância Sanitária (Anvisa). Resolução ANVISA/MS no 04 de 24 de novembro de 1988. Apêndice III que permite o uso de aditivos na alimentação. Brasil, 1988. Available at: $<$ http://bvsms.saude.gov. br/bvs/saudelegis/cns/1988/res0004_24_11_1988.html>. Accessed on: Jan. 20, 2021.

BRASIL. Agência Nacional de Vigilância Sanitária (Anvisa). Resolução ANVISA/MS n $n^{\circ} 28$, de 26 de maio de 2009. Regulamento Técnico para produtos e serviços que envolvam riscos à saúde pública, que incluí alimentos, considerando a Resolução GMC n 11 de 2006 Mercosul. Brasil, 2009. Available at: <http://bvsms.saude.gov.br/bvs/saudelegis/anvisa/2009/ res0028_26_05_2009.html>. Accessed on: Jan. 22, 2021.

BRASIL. Agência Nacional de Vigilância Sanitária (Anvisa). Resolução ANVISA/MS $n^{\circ} 340$ de 13 de dezembro de 2002. Regulamento Técnico que obriga as empresas fabricantes de alimentos que contenham em sua composição o corante tartrazina (INS 102) a declarar na rotulagem, a lista de ingredientes, o nome do corante tartrazina por extenso. Brasil, 2002. Available at: <resolucao-rdc-no-340-de-13-de-dezembro-de-2002.pdf $>$. Accessed on: Jan. 20, 2021.

BRASIL. Agência Nacional de Vigilância Sanitária (Anvisa). Resolução ANVISA/MS no 382, de 5 de agosto de 1999. Regulamento técnico que aprova o uso de aditivos alimentares, estabelecendo suas funções e seus limites máximos para a categoria de alimentos 13 - molhos e condimentos. Diário Oficial da União, Brasília, Seção 1, 9 ago. 1999. Available at: <http:// bvsms.saude.gov.br/bvs/saudelegis/anvisa/1999/res0382_05_08_1999.html>. Accessed on: Jan. 20, 2021.

BRASIL. Agência Nacional de Vigilância Sanitária (Anvisa). Resolução ANVISA/MS no 383 de 5 de agosto de 1999. Regulamento Técnico que aprova o uso de Aditivos Alimentares estabelecendo suas funções e seus limites máximos para a categoria de alimentos 7 - Produtos de Panificação e Biscoito. Diário Oficial da União, Brasília, Seção 1, 9 ago. 1999b. Available at: <http:// bvsms.saude.gov.br/bvs/saudelegis/anvisa/1999/res0383_05_08_1999.html>. Accessed on: Jan. 20, 2021.

BRASIL. Agência Nacional de Vigilância Sanitária (Anvisa). Resolução ANVISA/MS no 385, de 5 de agosto de 1999. Regulamento Técnico que aprova o uso de Aditivos Alimentares, estabelecendo suas Funções e seus Limites Máximos para a Categoria de Alimentos 6 - Cereais e Produtos de ou à Base de Cereais. Diário Oficial da União, Brasília, Seção 1, 9 ago. 1999c. Available at: $<$ http://bvsms.saude.gov.br/bvs/saudelegis/anvisa/1999/res0385_05_08_1999. html>. Accessed on: Jan. 20, 2021.

BRASIL. Agência Nacional de Vigilância Sanitária (Anvisa). Resolução ANVISA/ MS no 388, de 5 de agosto de 1999. Regulamento Técnico que aprova o uso de Aditivos Alimentares, estabelecendo suas Funções e seus Limites Máximos para a Categoria de Alimentos 19 - Sobremesas. Diário Oficial da União, Brasília, Seção 1, 9 ago. 1999d. Available at: <http://bvsms.saude.gov.br/bvs/saudelegis/anvisa/1999/ res0388_05_08_1999.html>. Accessed on: Jan. 20, 2021.

BRASIL. Agência Nacional de Vigilância Sanitária (Anvisa). Resolução ANVISA/MS n 389, de 5 de agosto de 1999. Regulamento Técnico que aprova o uso de Aditivos Alimentares, estabelecendo suas Funções e seus Limites Máximos para a Categoria de Alimentos 16: Bebidas - subcategoria 16.2.2 - Bebidas não Alcoólicas Gaseificadas e não Gaseificadas. Diário Oficial da União, Brasília, Seção 1, 9 ago. 1999e. Available at: <http://bvsms. saude.gov.br/bvs/saudelegis/anvisa/1999/res0389_05_08_1999.html>. Acesso 20 jan. 2021.

BRASIL. Agência de Vigilância Sanitária (Anvisa). Regulamentação de aditivos alimentares e coadjuvantes de tecnologia no Brasil. RDC $\mathrm{n}^{\circ} 285$, de 22 de maio de 2019. Brasil: Agência de Vigilância Sanitária, 2019. Available at: <https://www.in.gov.br/web/dou/-/resolucao-rdc-n-285-de-21-de-maiode-2019-118357056>. Accessed on: Jan. 21, 2021.
BRASIL. Ministério do Meio Ambiente. Conselho Nacional do Meio Ambiente. Resolução no 357, de 17 de março de 2005. Dispõe sobre a classificação dos corpos de água e diretrizes ambientais para o seu enquadramento, bem como estabelece as condições e padrões de lançamento de efluentes, e dá outras providencias. Brasil, 2005.

BRASIL. Ministério do Meio Ambiente. Conselho Nacional do Meio Ambiente. Resolução no 430, de 13 de maio de 2011. Dispõe sobre as condições e padrões de lançamentos de efluentes, complementa e altera a Resolução $\mathrm{n}^{\circ}$ 357, de 17 de março de 2005, do Conselho Nacional do Meio Ambiente. Brasil, 2011.

CEYHAN, B. M.; GULTEKIN, F.; DOGUC, D. K.; KULAC, E. Effects of maternally exposed coloring food additives on receptor expressions related to learning and memory in rats. Food and Chemical Toxicology, v. 56, p. 145-148, 2013. https://doi.org/10.1016/j.fct.2013.02.016

COLLINS, T. F.; BLACK, T. N.; BROWN, L. H.; BULHACK, P. Study of the teratogenic potential of FD\&C Yellow No. 5 when given by gavage to rats. Food and Chemical Toxicology, v. 28, n. 12, p. 821-827, 1990. https://doi. org/10.1016/0278-6915(90)90055-r

COLLINS, T. F.; BLACK, T. N.; O'DONNELL JR., M. W.; BULHACK, P. Study of the teratogenic potential of FD\&C yellow No. 5 when given in drinkingwater. Food and Chemical Toxicology, v. 30, n. 4, p. 263-268, 1992. https://doi. org/10.1016/0278-6915(92)90002-3

CONNOLLY, A.; HEARTY, A.; NUGENT, A.; MCKEVITT, A.; BOYLAN, E.; FLYNN, A. Pattern of intake of food additives associated with hyperactivity in Irish children and teenagers. Food Additives \& Contaminants Part A: Chemistry, Analysis, Control, Exposure \& Risk Assessment, v. 27, n. 4, p. 447456, 2010. https://doi.org/10.1080/19440040903470718

CORDER, E. H.; BUCKLEY, E. Aspirin, salicylate sulphite and tartrazine induced bronchoconstriction, safe doses and case definition in epidemiological studies. Journal of Clinical Epidemiology, v. 48, n. 10, p. 1269-1275, 1995. https://doi.org/10.1016/0895-4356(95)00017-x

COSMOQUÍMICA INDÚSTRIA \& COMÉRCIO LTDA. Ficha de informações de segurança de produto químico - corante amarelo tartrazina. Informe técnico. São Paulo: Cosmoquímica Indústria \& Comércio Ltda, 2009. 5 p. Available at: $<$ http://cosmoquimica2.tempsite $>$. Accessed on: Mar 4, 2020.

DAVIS, V. M.; BAILEY JR., J. E. Chemical reduction of FD\&C Yellow No. 5 to determine combined benzidine. Journal of Chromatography, v. 635, n. 1, p. 160-164, 1993. https://doi.org/10.1016/0021-9673(93)83128-F

DEL GIOVINE, L.; BOCCA, A. P. Determination of synthetic dyes in ice cream by capillary electrophoresis. Food Control, v. 14, n. 3, p. 131-135, 2003. https://doi.org/10.1016/S0956-7135(02)00055-5

DEMIRKOL, O.; ZHANG, X.; ERCAL, N. Oxidative effects of Tartrazine (CAS No. 1934-21-0) and New Coccin (CAS No. 2611-82-7) azo dyes on CHO cells. Journal für Verbraucherschutz und Lebensmittelsicherheit, v. 7, p. 229-236, 2012. https://doi.org/10.1007/s00003-012-0782-z

DIXIT, S.; PURSHOTTAM, S. K.; KHANNA, S. K.; DAS, M. Usage pattern of synthetic food colours in different states of India and exposure assessment through commodities preferentially consumed by children. Food Additives \& Contaminants Part A: Chemistry, Analysis, Control, Exposure \& Risk Assessment, v. 28, n. 8, p. 996-1005, 2011. https://doi.org/10.1080/19440049.20 11.580011

DOELL, D.; FOLMER, D.; LEE, H.; BUTTS, K.; CARBERRY, S. Exposure estimate for FD\&C colours for the US population. In: NATIONAL MEETING OF THE AMERICAN CHEMICAL SOCIETY, 250., 2015, Boston. Washington: United States Food and Drug Administration, 2015. 
DOGUC, D. K.; CEYHAN, B. M.; OZTURK, M.; GULTEKIN, F. Effects of maternally exposed colouring food additives on cognitive performance in rats. Toxicology and Industrial Health, v. 29, n. 7, p. 616-623, 2013. https://doi. org/10.1177/0748233712436638

ELHKIM, M. O.; HERAUD, F.; BEMRAH, N.; GAUCHARD, F.; LORINO, T.; LAMBRÉ, C.; FRÉMY, J. M.; POUL, J.-M. New considerations regarding the risk assessment on tartrazine. An update toxicological assessment, intolerance reactions and maximum theoretical daily intake in France. Regulatory Toxicology and Pharmacology, v. 47, n. 3, p. 308-316, 2007. https://doi. org/10.1016/j.yrtph.2006.11.004

EL-SAKHAWY, M. A.; MOHAMED, D. W.; AHMED, Y. H. Histological and immunohistochemical evaluation of the effect of tartrazine on the cerebellum, submandibular glands, and kidneys of adult male albino rats. Environmental Science and Pollution Research, v. 26, n. 10, p. 9574-9584, 2019. https://doi. org/10.1007/s11356-019-04399-5

EL-WAHAB, H. M.; MORAM, G. S. Toxic effects of some synthetic food colorants and/or flavour additives on male rats. Toxicology and Industrial Health, v. 29, n. 2, p. 224-232, 2013. https://doi.org/10.1177/0748233711433935

ERICKSON, Z. T.; FALKENBERG, E. A.; METZ, G. A. Lifespan psychomotor behavior profiles of multigenerational prenatal stress and artificial food dye effects in rats. PLoS One, v. 9, n. 6, e92132, 2014. https://doi.org/10.1371/ journal.pone.0092132

EUROPEAN FOOD SAFETY AUTHORITY (EFSA). Scientific opinion on the re-evaluation of tartrazine (E 102). Panel on Food Additives and Nutrient Sources Added to Food. The EFSA Journal, v. 7, n. 11, p. 1331-1383, 2009. https://doi.org/10.2903/j.efsa.2009.1331

FÁVERO, D. M.; RIBEIRO, C. S. G.; AQUINO, A. D. Sulfitos: importância na indústria alimentícia e seus possíveis malefícios a população. Segurança Alimentar e Nutricional, v. 18, n. 1, p. 11-20, 2011. https://doi.org/10.20396/ san.v18i1.8634684

FIRDAUS, A.; ANDARWULAN, N.; HARIYADI, P. Tartrazine exposure assessment by using food frequency method in North Jakarta, Indonesia. Food and Nutrition Sciences, v. 2, n. 5, p. 458-463, 2011. https://doi.org/10.4236/ fns.2011.25065

FLORIANO, J. M.; ROSA, E.; AMARAL, Q. D. F.; ZURAVSKI, L.; CHAVES, P. E. E.; MACHADO, M. M.; OLIVEIRA, L. F. S. Is tartrazine really safe? In silico and ex vivo toxicological studies in human leukocytes: a question of dose. Toxicology Research, v. 7, n. 6, p. 1128-1134, 2018. https://doi.org/10.1039/ c8tx00034d

FOOD AND DRUG ADMINISTRATION (FDA). Code of Federal Regulations Title 21. v. 1. 74.705 FD \& C Yellow No. 5. FDA, 2019. Available at: <www.ata. fda.gov/>. Accessed on: Mar, 2020.

FREITAS, A. S. Tartrazina: uma revisão das propriedades e análises de quantificação. Acta Tecnológica, v. 7, n. 2, p. 65-72, 2012. https://doi. org/10.35818/acta.v7i2.90

FSANZ. Supplementary report to the 2008 Survey of added colours in foods available in Australia. Canberra: Food Standards Australia New Zealand, 2012.

GAO, Y.; LI, C.; SHEN, J.; YIN, H.; AN, X.; JIN, H. Effect of Food Azo Dye Tartrazine on Learning and Memory Functions in Mice and Rats, and the Possible Mechanisms Involved. Journal of Food Science, v. 76, n. 6, p. T125-T129, 2011. https://doi.org/10.1111/j.1750-3841.2011.02267.x

GHONIMI, W. A.; ELBAZ, A. Histological changes of selected Westar rat tissues following the ingestion of tartrazine with special emphasis on the protective effect of royal jelly and cod liver oil. Journal of Cytology \& Histology, v. 6, n. 4, p. 346, 2015. https://doi.org/10.4172/2157-7099.1000346
GIRI, A K.; DAS, S. K.; TALUKDER, G.; SHARMA, A. Sister chromatid exchange and chromosome aberrations induced by curcumin and tartrazine on mammalian cells in vivo. Cytobios, v. 62, n. 249, p. 111-117, 1990.

GOMES, K. M. S.; OLIVEIRA, M. V. G. A; CARVALHO, F. R. S.; MENEZES, C. C.; PERON, A. P. Citotoxicity of food dyes Sunset Yellow (E-110), Bordeaux Red (E-123), and Tatrazine Yellow (E-102) on Allium cepa L. root meristematic cells. Food Science Technology, v. 33, n. 1, p. 218-223, 2013. http:// doi.org/10.1590/S0101-20612013005000012

GUPTA, R.; RANJAN, S.; YADAV, A.; VERMA, B.; MALHOTRA, K.; MADAN, M.; CHOPRA, O.; JAIN, S.; GUPTA, S.; JOSHI, A.; BHASIN, C.; MUDGAL, P. Toxic Effects of Food Colorants Erythrosine and Tartrazine on Zebrafish Embryo Development. Current Research in Nutrition and Food Science, v. 7, n. 3, p. 876-885, 2019. http://doi.org/10.12944/CRNFSJ.7.3.26

HA, M. S.; HA, S. D.; CHOI, S. H.; BAE, D. H. Exposure assessment of synthetic colours approved in Korea. Food Additives \& Contamination, v. 30, n. 4, p. 643-653, 2013. https://doi.org/10.1080/19440049.2013.768358

HASHEM, M. M.; ABD-ELHAKIM, Y. M.; ABO-EL-SOOUD, K.; MONA M. E. ELEIWA, M. M. E. Embryotoxic and Teratogenic Effects of Tartrazine in Rats. Toxicol. Res., v. 35, n. 1, p. 75-81, 2019. https://doi.org/10.5487/TR.2019.35.1.075

HIMRI, I.; BELLAHCEN, S.; SOUNA, F.; BELMEKKI, F.; AZIZ, M.; BNOUHAM, M.; ZOHEIR, J.; BERKIA, Z.; MEKHFI, H.; SAALAOUI, E. A 90-day oral toxicity study of tartrazine, a synthetic food dye, in wistar rats. International Journal of Pharmacy and Pharmaceutical Sciences, v. 3, n. 3, p. 159-169, 2011

HORVAT, A. J. M.; BABIC, S.; PAVLOVIC, D. M.; ASPERGER, D.; PELKO, S.; KASTELAN-MACAN, M.; PETROVIC, M.; MANCE, A. D. Analysis, occurrence and fate anthelmintcs and their transformation products in the environment. Trends in Analytical Chemistry, v. 31, p. 61-84, 2012. https://doi. org/10.1016/j.trac.2011.06.023

HUNGER, K. Industrial dyes: chemistry, properties, applications. Weinheim: Wiley-VCH Publishers, 2003.

INTERNATIONAL ASSOCIATION OF COLOR MANUFACTURERS (IACM). Safety evaluation of the food colour additive tartrazine (INS 102). Washington, D.C.: IACM, 2015.

JIANG, L.-L.; LI, K.; YAN, D.-L.; YANG, M.-F.; MA, L.; XIE, L.-Z. Toxicity Assessment of 4 Azo Dyes in Zebrafish Embryos. International Journal of Toxicology, v. 39, n. 2, p. 115-123, 2020. https://doi. org/10.1177\%2F1091581819898396

JOSHI, V.; KATTI, P. Developmental Toxicity Assay for Food Additive Tartrazine Using Zebrafish (Danio rerio) Embryo Cultures. International Journal of Toxicology, v. 37, n. 1, p. 38-44, 2017. https://doi. org/10.1177\%2F1091581817735227

KAMEL, M. M.; EL-LETHEY, H. The Potential Health Hazard of Tartrazine and Levels of Hyperactivity, Anxiety-Like Symptoms, Depression and Antisocial behaviour in Rats. Journal of American Science, v. 7, n. 6, p. 1211-1218, 2011.

KASHANIAN, S.; ZEIDALI, S. H. Binding Studies of Tartrazine Food Additive. DNA and Cell Biology, v. 30, n. 7, p. 499-505, 2011. https://doi. org/10.1089/dna.2010.1181

KHAYYAT, L.; ESSAWY, A.; SOROUR, J.; SOFFAR, A. Tartrazine induces structural and functional aberrations and genotoxic effects in vivo. Peer Journal, v. 5, e3041, 2017. https://doi.org/10.7717/peerj.3041

LINSKENS, A. The Long Term Effects of Tartrazine (FD\&C Yellow No. 5) on Learning, Cognitive Flexibility, and Memory of Zebrafish (Danio rerio) Embryos into Adulthood. 2018. Available at: $<$ https://cpb-us-w2. 
wpmucdn.com/sites.uwm.edu/dist/8/202/files/2018/06/Linskens_paper_LM_ Seymour_2018-1lxiur8.pdf>. Accessed on: Mar 7, 2020.

LOK, K. Y.; CHUNG, W. Y.; BENZIE, I.; WOO J. Colour additives in snack foods consumed by primary school children in Hong Kong. Food Additive \& Contaminants Part B Surveillance, v. 3, n. 3, p. 148-155, 2010.

MAEKAWA, A.; MATSUOKA, C.; ONODERA, H.; TANIGAWA, H.; FURUTA, K.; KANNO, J.; JANG, J. J.; HAYASHI, Y.; OGIU, T. Lack of carcinogenicity of tartrazine (FD\&C Yellow No. 5) in the F344 rat. Food and Chemical Toxicology, v. 25, n. 12, p. 891-896, 1987. https://doi. org/10.1016/0278-6915(87)90281-x

MATHUR, N.; BHATNAGAR, P.; SHARMA, P. Review of the Mutagenicity of textile Dye Products. Universal Journal of Environmental Research and Technology, v. 2, n. 2, p. 1-18, 2012.

MATSUO, H.; YOKOOJI, T.; MORITA, H.; OOI, M.; URATA, K.; ISHII, K.; TAKAHAGI, S.; YANASE, Y.; HIRAGUN, T.; MIHARA, S.; HIDE, M. Aspirin Augments IgE-Mediated Histamine Release from Human Peripheral Basophils via Syk Kinase Activation. Allergology International, v. 62, n. 4, p. 503-511, 2013. https://doi.org/10.2332/allergolint.13-OA-0536

MATSUZAKI, M.; MUCCI, J. L. N.; ROCHA, A. A. Comunidade fitoplanctônica de um pesqueiro na cidade de São Paulo. Revista Saúde Pública, v. 38, n. 5, p. 679-686, 2004. https://doi.org/10.1590/S003489102004000500010

MCCANN, D.; BARRETT, A.; COOPER, A.; CUMPLER, D.; DALEN, L.; GRIMSHAW, K.; KITCHIN, E.; LOK, K.; PORTEOUS, L.; PRINCE, E.; SONUGA-BARKE, E.; WARNER, J. O.; STEVENSON, J. Food additives and hyperactive behavior in 3-year-old and 8/9-year-old children in the community: a randomised, double-blinded, placebo-controlled trial. Lancet, v. 370, n. 9598, p. 1560-1567, 2007. https://doi.org/10.1016/S01406736(07)61306-3

MEDEIROS, A. M. Z.; SILVA, G. H.; CASTRO, V. L. S. S.; MONTEIRO, R. T. R.; MARTINEZ, D. S. T. Nanoecotoxicidade do óxido de grafeno: influência do córion dos embriões de zebrafish (Danio rerio) e coexposição com ácido húmico. In: WORKSHOP DE NANOTECNOLOGIA APLICADA AO AGRONEGÓCIOS. Anais [...]. São Carlos: Empraba Instrumentação, 2017.

MEYER, S. K.; PROBERT, P. M. E.; LAKEY, A. F.; AXON, A. R.; LEITCH, A. C.; WILLIAMS, F. M.; JOWSEY, P. A.; BLAIN, P. G.; KASS, G. E. N.; WRIGHT, M. C. Hepatic effects of tartrazine (E 102) after systemic exposure are independent of oestrogen receptor interactions in the mouse. Toxicology Letter, v. 273, p. 55-68, 2017. https://doi.org/10.1016/j.toxlet.2017.03.024

MOHAMED, A. A.; GALAL, A. A.; ELEWA, Y. H. Comparative protective effects of royal jelly and cod liver oil against neurotoxic impact of tartrazine on male rat pups brain. Acta Histochemica, v. 117, n. 7, p. 649-658, 2015. https:// doi.org/10.1016/j.acthis.2015.07.002

MORAIS, L. S. T. Avaliação clínico-laboratorial do uso da tartrazina em pacientes atópicos: amostra ampliada. 82f. Dissertation (Mastering) - Programa de Pós-Graduação em Ciências Médicas, Universidade Federal Fluminense, Niterói, 2010.

MOUTINHO, I. L. D. A.; BERTGES, L. C. B.; ASSIS, R. V. C. Prolonged use of the food dye tartrazine (FD\&C yellow $n^{\circ} 5$ ) and its effects on the gastric mucosa of Wistar rats. Brazilian Journal of Biology, v. 67, n. 1, p. 141-145, 2007.

MPOUNTOUKAS, P.; PANTAZAKI, A.; KOSTARELI, E.; CHRISTODOULOU, P.; KARELI, D.; POLILIOU, S.; MOURELATOS, C.; LAMBROPOULOU, V.; LIALIARIS, T. Cytogenetic evaluation and DNA interaction studies of the food colorants amaranth, erythrosine and tartrazine. Food and Chemical Toxicology, v. 48, n. 10, p. 2934-2944, 2010. https://doi. org/10.1016/j.fct.2010.07.030
PAN, X.; QIN, P.; LIU, R.; WANG, J. Characterizing the Interaction between Tartrazine and Two Serum Albumins by a Hybrid Spectroscopic Approach. Journal of Agricultural and Food Chemistry, v. 59, n. 12, p. 6650-6656, 2011. https://doi.org/10.1021/jf200907x

PARLAMENTO EUROPEU. Diretiva 95/45/CE do Parlamento Europeu e do Conselho de 26 de julho de 1995. Diário Oficial das Comunidades Europeias, p. 1, L 226, 22 set. 1995.

PATTERSON, R. M.; BUTLER, J. S. Tartrazine-induced chromosomal aberrations in mammalian cells. Food and Chemical Toxicology, v. 20, n. 4, p. 461-465, 1982. https://doi.org/10.1016/S0278-6915(82)80113-0

POLLOCK, I.; WARNER, J. O. Effect of artificial food colours on childhood behaviour. Archives of Disease in Childhood, v. 65, n. 1, p. 74-77, 1990.

POLÔNIO, M. L. T.; PERES, F. Consumo de aditivos alimentares e efeitos à saúde: desafios para a saúde pública brasileira. Cadernos de Saúde Pública, Rio de Janeiro, v. 25, n. 8, p. 1653-1666, 2009. https://doi.org/10.1590/S0102311X2009000800002

PRADO, M. A.; GODOY, H. T. Corantes artificiais em alimentos. Alimentos e Nutrição, v. 14, n. 2, p. 237-250, 2003.

PRIVAL, M. J.; DAVIS, V. M.; PEIPERL, M. D.; BELL, S. J. Evaluation of azo food dyes for mutagenicity and inhibition of mutagenicity by methods using Salmonella typhimurium. Mutation Research, v. 206, n. 2, p. 247-259, 1988. https://doi.org/10.1016/0165-1218(88)90168-1

PRIVAL, M. J.; MITCHELL, V. M. Analysis of a method for testing azo dyes for mutagenic activity in Salmonella typhimurium in the presence of Flavin mononucleotide and hamster liver S9. Mutation Research, v. 97, n. 2, p. 103116, 1982. https://doi.org/10.1016/0165-1161(82)90008-5

PRIVAL, M. J.; PEIPERL, M. D.; BELL, S. J. Determination of combined benzidine in FD \& C yellow no. 5 (tartrazine), using a highly sensitive analytical method. Food and Chemical Toxicology, v. 31, n. 10, p. 751-758, 1993. https://doi.org/10.1016/0278-6915(93)90147-Q

RESENDE, M. R. Mutagenicidade do corante alimentício tartrazina no ensaio salmonella/microssoma. 118f. Dissertation (Mastering) - Faculdade de Tecnologia, Universidade Estadual de Campinas, Campinas, 2015.

SASAKI, Y. F.; KAWAGUCHI, S.; KAMAYA, A.; OHSHITA, M.; KABASAWA, K.; IWAMA, K.; TANIGUCHI, K.; TSUDA, S. The comet assay with 8 mouse organs: results with 39 currently used food additives. Mutation Research, v. 519, n. 1-2, p. 103-119, 2002. https://doi.org/10.1016/s1383-5718(02)00128-6

SAXENA, B.; SHARMA, S. Food colour induced hepatotoxicity in Swiss albino rats Rattus norvegicus. Toxicology International, v. 22, n. 1, p. 152-157, 2015. https://doi.org/10.4103\%2F0971-6580.172286

SAXENA, B.; SHARMA, S. Serological changes induced by blend of sunset yellow, metanil yellow, and tartrazine in Swiss albino rats Rattus norvegicus. Toxicology International, v. 21, n. 1, p. 65-68, 2014. https://doi. org/10.4103/0971-6580.128798

SHORE, J. Colorants and auxiliaries: organic chemistry and application properties. 2. ed. Bradford: Society of Dyers and Colorists, 2002. v. 1.

SILVA, J.; FRACÁCIO, R. Toxicity of yellow tartrazine dye on Danio rerio larvae after a multi-generation exposure. 2020. (no prelo.)

SOARES, B. M. S.; ARAÚJO, T. M. T.; RAMOS, J. A. B.; PINTO, L. C.; KHAYAT, B. M.; BAHIA, M. O.; MONTENEGRO, R. C.; BURBANO, R. M. R., KHAYAT, A. S. Effects on DNA repair in human lymphocytes exposed to the food dye tartrazine yellow. Anticancer Research, v. 35, n. 3, p. 1465-1474, 2015.

STEVENSON, J.; SONUGA-BARKE, E.; MCCANN, D.; GRIMSHAW, K.; PARKER, K. M.; ROSE-ZERILLI, M. J.; HOLLOWAY, J. W.; WARNER, J. O. 
The role of histamine degradation gene polymorphisms in moderating the effects of food additives on children's ADHD symptoms. American Journal of Psychiatry, v. 167, n. 9, p. 1108-1115, 2010. https://doi.org/10.1176/appi. ajp.2010.09101529

SUH, H. J.; CHOI, S. Risk assessment of daily intakes of artificial colours additives commonly consumed in Korea. Journal of Food and Nutrition Research, v. 51, n. 1, p. 13-22, 2012.

TANAKA, T. Reproductive and neurobehavioural toxicity study of tartrazine administered to mice in the diet. Food and Chemical Toxicology, v. 44, n. 2, p. 179-187, 2006. https://doi.org/10.1016/j.fct.2005.06.011

TEIXEIRA, C.; PORTO, R. Avaliação da qualidade da água e autodepuração dos rios da Bacia do Rio Piracicaba. Revista Brasileira de Ciências Ambientais
(Online), n. 16, p. 20-31, 2008. Available at: <http://www.rbciamb.com.br/ index.php/Publicacoes_RBCIAMB/article/view/427>. Accessed on: May 2020. WORLD HEALTH ORGANIZATION (WHO). Safety evaluation of certain food additives: prepared by the Eighty-second meeting of the Joint FAO/ WHO Expert Committee on Food Additives (JECFA). Geneva: World Health Organization, 2017 (WHO Food Additives Series, No. 73).

ZANONI, M. V. B.; YAMANA, K. A. Corantes: caracterização química, toxicológica, métodos de detecção e tratamento. São Paulo: Cultura Acadêmica, 2017.

ZOLLINGER, H. Color chemistry: syntheses, properties, and applications of organic dyes and pigmens. Whiley: VCH, 1991. v. 3. 492 p. 